\title{
Meningkatkan Hasil Belajar Matematika Materi Pecahan Dengan Benda Kongkrit Pada Siswa Kelas II SDN Tuban Tahun Pelajaran 2017/2018
}

\author{
Kimin \\ Guru Kelas SDN Tuban Kecamatan Pujut Kabupaten Lombok Tengah
}

\begin{abstract}
Abstrak. Penelitian ini dilakukan di SDN Tuban tahun pelajaran 2017 / 2018 dengan tujuan untuk meningkatkan Hasil Belajar Matematika Materi Pecahan dengan Peraga Benda Kongkrit pada siswa kelas II, penelitian dimulai dari bulan juli sampai dengan bulan september 2017, dimana hasil belajar siswa terus mengalami peningkatan yang cukup signifikan mulai dari siklus 1 menuju sikus II ini dibuktikan dengan perolehan nilai hasil belajar siswa. Pada siklus I memperoleh nilai rata - rata sebesar 68,47 dengan persentase ketuntasan $63 \%$ atau sebanyak 12 orang dari 19 sudah tuntas belajar dan siswa yang tidak tuntas sebanyak $37 \%$ atau 7 orang siswa belum tuntas belajar ini dikarenakan siswa terlalu banyak main - main dan guru kurang kontrol di dalam kelas,karena ketuntasan klasikal yang dipatok sebesar $\geq 80 \%$ belum tercapai maka penelitian ini dilanjutkan kesiklus berikutnya. Kemudian hasil belajar siswa siklus II ,memperoleh nilai rata - rata sebesar 83,52 dan persentase ketuntasan $95 \%$ atau sebanyak 18 siswa sudah tuntas belajar dan persentase siswa yang tidak tuntas sebanyak $5 \%$ atau 1 orang siswa belum tuntas belajar, begitu juga dengan ketuntasan klasikal yang dipersyaratkan sebesar $\geq 80 \%$ juga sudah tercapai, ini dikarenakan guru mampu mengatasi kendala - kendala yang terjadi pada siklus I, maka dengan demikian penelitian ini di hentikan sampai pada siklus II. Jika dilihat perbandingan hasil belajar pada siklus 1 memperoleh nilai rata - rata sebesar 68,47 kemudian meningkat pada siklus II menjadi 83,52 terjadi peningkatan sebesar 15,05 poin, begitu juga dengan persentase ketuntasan belajar pada siklus I mencapai $63 \%$ atau sebanyak 12 siswa yang tuntas belajar da pada siklus II meningkat menjadi persentase ketuntasan belajar sebesar $95 \%$ atau 18 siswa yang tuntas belajar terjadi peningkatan sebesar 33 poin dari siklus I menju siklus II, dan ketuntasan klasikal yang dipersyaratkan sebesar $\geq 80 \%$ pun juga sudah tercapai pada siklus II. Dengan demikian penggunaan media kongkrit dapat dijadikan sebagai salah satu metode pembelajaran pecahan sederhana.
\end{abstract}

Kata Kunci: Hasil Belajar, Benda Kongkrit, Materi Pecahan

\section{PENDAHULUAN}

\section{Latar Belakang Masalah}

Keberhasilan proses pembelajaran merupakan hal utama yang didambakan dalam pelaksanaan pendidikan di sekolah. Pada era globalisasi ini penerapan ilmu pengetahuan dan tekhnologi harus didukung oleh sumber daya manusia yang berkualitas tinggi. Matematika sebagai salah satu ilmu dasar dewasa ini telah berkembang amat pesat, baik materi maupun kegunaannya. Namun sayang, sampai saat sekarang Matematika masih dipandang sebagai pelajaran yang membosankan dan tidak menarik.

Komponen utama dalam proses pembelajaran adalah guru dan siswa. Ditinjau dari komponen guru, agar proses pembelajaran berhasil, guru harus dapat membimbing siswa sedemikian rupa sehingga mereka dapat mengembangkan pengetahuannya sesuai dengan struktur pengetahuan mata pelajaran yang dipelajarinya ditinjau dari komponen siswa, keberhasilan belajar sangat ditentukan oleh konsep-konsep yang relevan yang telah dimiliki siswa pada awal(sebelum) mempelajari materi tertentu.

Ketidak berminatan siswa terhadap mata pelajaran Matematika dalam hal ini pecahan terbukti dari hasil ulangan harian pada mata pelajaran Matematika siswa kelas II SDN Tuban hasilnya masih belum maksimal karena masih di bawah KKM yang yang ditetapkan oleh SDN Tuban tahun pelajaran 2017/2018 yaitu 70, dan jumlah siswa kelas II sebanyak 19 orang. Hasil belajar siswa pada saat ulangan yang 
tuntas sebanyak 12 orang atau $62 \%$ dan sisanya sebanyak 7 orang siswa belum mencapai KKM untuk mata pelajaran Matematika persentase sebesar $37 \%$,dengan ketuntasan klasikal $\geq 85 \%$.

Rendahnya capaian nilai KKM disebabkan oleh pelajaran Matematika dirasakan sukar, merupakan konsepkonsep yang abstrak, persepsi yang negatif Banyak hal yang dapat dikaji untuk mengungkap masalah tersebut, mungkin bersumber dari porsi materinya yang tidak sesuai, strategi pembelajarannya kurang tepat dan cara penyajian aturan-aturan yang tidak jelas asal-usulnya.

Untuk mengatasi persepsi yang negatif tersebut, guru mempunyai peranan yang sangat penting, maka dalam kegiatan belajar mengajar guru hendaknya mampu memilih dan menggunakan strategi yang melibatkan siswa aktif dalam belajar, baik secara mental, fisik, maupun sosial. Bagaimana agar siswa itu belajar aktif? Agar siswa belajar aktif, hendaknya pengajaran Matematika itu: menarik minat siswa, dalam pembelajaran menggunakaan benda konkrit untuk menjelaskan konsepkonsep Matematika yang bersifat abstrak.

Oleh sebab itu pada kesempatan ini peneliti menekankan pembelajaran Matematika pada penggunaan alat peraga benda konkret untuk membantu mengungkap dan menjelaskan materi pecahan pada siswa kelas dua sehingga peneliti melakukan penelitian dengan judul" Meningkatkan Hasil Belajar Matematika Materi Pecahan dengan Peraga Benda Kongkrit Pada Siswa Kelas II SDN Tuban Tahun Pelajaran 2017/2018”

\section{Rumusan Masalah}

Rumusan masalah pada penelitian ini adalah Bagaimanakah Meningkatkan Hasil Belajar Matematika Materi Pecahan dengan Peraga Benda Kongkrit pada Siswa Kelas II SDN Tuban Tahun Pelajaran 2017/2018?

\section{Tujuan Penelitian}

Tujuan penelitian tindakan kelas ini adalah untuk Meningkatkan Hasil Belajar Matematika Materi Pecahan dengan Peraga Benda Kongkrit pada Siswa Kelas II SDN
Tuban Tahun Pelajaran 2017/2018”

\section{Manfaat Penelitian}

Manfaat diri penelitian ini adalah dapat membangkitkan motovasi dan rasa percaya diri siswa sehingga hasil belajar siswa meningkat. Bagi lembaga sebagai masukan mengenai keebijakan yang akan di tetapkan dalam rangka meningkatkan mutu sekolah.

\section{LANDASAN TEORI DAN KAJIAN PUSTAKA}

Pengertian Belajar

Pengertian belajar menurut beberapa ahli pendidikan tidaklah sama. Namun perbedaan tersebut justru akan menambah wawasan kita dalam pengetahuan tentang belajar. Menurut Sudjana (2005:5) mengartikan belajar sebagai berikut.

Belajar adalah suatu proses yang harus disadari dengan perubahan pada diri seseorang sebagai hasil proses dalam bentuk pengetahuan, sikap dan tingkah laku, keterampilan, kecakapan, kebiasaan, serta perubahan aspek-aspek lain pada individu yang belajar. Perubahan tingkah laku tersebut karena adanya interaksi.

Menurut WS. Winkel (dalam Belajar Pembelajaran TIM IKIP Semarang, 2006:2) menjelaskan bahwa "belajar adalah suatu aktivitas mental/psikis yang berlangsung dalam interaksi aktif dengan lingkungan, yang menghasilkan perubahan-perubahan dalam pengetahuan, pemahaman, kemampuan, dan perubahan sikap-sikap itu bersifat relatif, konstan, dan berbekas."

Dari uraian pengertian di atas secara umum dapat disimpulkan bahwa belajar adalah suatu proses usaha yang dilakukan oleh individu untuk memperoleh perubahan tingkah laku yang baru secara keseluruhan, sebagai pengalaman individu itu sendiri dalam berinteraksi dengan lingkungan.

\section{Prinsip-prinsip Belajar}

Proses belajar itu komplek sekali, tetapi juga dapat dianalisis dan diperinci dalam bentuk asas-asas atau prinsipprinsip belajar. Menurut Abu Ahmadi (2006:14) prinsip-prinsip itu adalah 
sebagai berikut (a) Belajar harus bertujuan dan terarah, (b) Belajar memerlukan bimbingan.,(c) Belajar memerlukan atas hal-hal yang dipelajari sehingga memperoleh pengertian-pengertian, (c) Belajar memerlukan latihan dan ulangan agar apa yang telah dipelajari dapat dikuasainya, (d) Belajar adalah suatu proses aktif dimana saling terjadi pengaruh secara dinamis antara murid dengan lingkungannya, (d) Belajar dianggap berhasil ke dalam bidang praktik seharihari.

Disamping uraian di atas yang juga tidak kalah pentingnya dalam belajar adalah motivasi, sebab setiap individu mempunyai kebutuhan atau keinginan. Setiap keinginan atau kebutuhan perlu memperoleh pemenuhan kebutuhan.

\section{Faktor-faktor yang Mempengaruhi Belajar}

Pada proses belajar mengajar, hasil belajar siswa dapat dipengaruhi oleh dua faktor, yaitu faktor dari dalam (Internal) dan faktor yang berasal dari luar (external). (a) Faktor dari dalam (internal). Yaitu faktor yang berasal dari diri siswa yang sedang belajar, (b) Faktor dari luar (external). Yaitu faktor-faktor yang dapat mempengaruhi hasil belajar yang berasal dari luar diri siswa.

Pengajaran Matematika

Menurut Anton M. Moeliono (2000:566), Matematika diartikan sebagai "ilmu tentang bilangan-bilangan, hubungan antara bilangan, dan prosedur operasional yang digunakan dalam penyelesaian masalah mengenai bilangan". Namun, sampai sekarang di antara para ahli Matematika belum ada kesepakatan yang bulat untuk memberikan jawaban definisi tentang Matematika secara baku.

Menurut R. Soedjadi dan Masriyah (2004:1), menyatakan Meskipun terdapat berbagai pendapat yang tampaknya berlainan, tetapi dapat ditarik ciri-ciri yang sama, yakni Matematika mempunyai objek kajian yang abstrak, Matematika mendasarkan diri pada kesepakatan-kesepakatan, Matematika sepenuhnya menggunakan pola pikir deduktif, dan Matematika dijiwai dengan kebenaran konsistensi.

Pada hakekatnya pengajaran Matematika di sekolah memiliki kegunaan yang kompleks, yakni kegunaan untuk kepentingan Matematika sendiri dan kegunaan dalam kehidupan sehari-hari di bidang non Matematika

Fungsi dan Tujuan Pengajaran

Matematika

. Adapun fungsi dan tujuan itu

menurut Garis-garis Besar Program

Pengajaran adalah sebagai berikut.

1) Fungsi Pengajaran Matematika

Fungsi sebagai alat Hal ini disebabkan karena Matematika dapat digunakan dalam berbagai bidang ilmu pengetahuan dalam kehidupan sehari hari ,sebagai pola pikir dalam berpikir kritis.

2) Tujuan Pembelajaran

\section{Matematika}

Siswa dapat menggunakan konsep, mengenal lambang, dan istilah atau nama, serta menemukan rumus (prinsip),melakukan operasi yang ada dalam matematika,menggunakan konsep dan memiliki sifat kritis dan terbuka.

Dari uraian fungsi dan tujuan pengajaran diatas secara umum pendidikan Matematika pada jenjang pendidikan dasar dan pendidikan menengah memberi tekanan pada penataan nalar, pembentukan sikap siswa dalam kehidupan sehari-hari dan dalam mempelajari berbagai ilmu pengetahuan serta juga memberi tekanan pada keterampilan dalam penerapan Matematika .

Teori Belajar Matematika

Ada beberapa teori belajar yang populer dan cocok untuk diterapkan pada pembelajaran Matematika di Pendidikan Dasar, diantaranya adalah sebagai berikut: (a) Teori belajar dari William Brownell. Menurut William Brownell, dalam mengerjakan Matematika di Pendidikan Dasar sebaiknya: 1) Menggunakan alat peraga benda konkret, 2) materi disajikan secara permanen dan terus menerus dalam jangka waktu yang lama. (b) Teori belajar dari Richard Skemp. Menurut Richard 
Skemp (dalam Amin Suyitno, 2005:35), belajar Matematika perlu dua tahap, yaitu sebagai berikut; 1) Perlu menggunakan benda-benda konkret untuk memberikan basis bagi siswa dalam menghayati ide-ide Matematika yang abstrak.1) Tingkat abstrak, yaitu mulai meninggalkan benda konkret untuk menuju kepemahaman Matematika yang memang memuat objekobjek abstrak.

Dari beberapa teori belajar Matematika di atas, maka dapat ditarik kesimpulan bahwa pembelajaran Matematika di Pendidikan Dasar sangat diperlukan suatu media pengajaran Matematika .

\section{Media Pengajaran Matematika}

b. Hubungan antar Media dan Proses

Pembelajaran

Pada hakikatnya pembelajaran (belajar dan mengajar) merupakan proses komunikasi antar guru dan siswa. Sebagai komunikasi pada proses pembelajaran di atas adalah siswa, sedangkan komunikatornya adalah guru dan siswa. Jika sekelompok siswa menjadi komunikator terhadap siswa lainnya dan guru sebagai fasilitator, maka akan terjadi proses interaksi dengan kadar pembelajaran yang tinggi.

c. Pengertian Media Pembelajaran

Menurut Anderson; Alat peraga sebagai media atau perlengkapan yang digunakan untuk membantu guru mengajar.

d. Pentingnya Media atau Alat Peraga Nilai praktis media pengajaran antara lain adalah mampu mengatasi keterbatasan ruang kelas,ukuran benda,kecepatan dan daya abstraksi siswa.

\section{Pegertian Pecahan}

Dunia ini penuh dengan pecahan. Jika tidak ada pecahan, maka tidak akan bisa berbagi kue dengan orang lain, dan harus membeli semuanya secara utuh atau tidak membeli sama sekali. Apakah pecahan itu? Pecahan adalah salah satu cara untuk menuliskan bilangan. Pecahan menunjukkan bahwa jika sebuah bilangan merupakan bagian dari satu bilangan utuh (Lynette Long dalam John Wiley \& Sons, Inc, 2003:1) Dengan kata lain pecahan adalah bilangan yang dinyatakan a/b dimana $a$ bilangan bulat, $b$ bilangan bulat, $b \neq 0$, dan $b$ bukan faktor dari pembilang.

a. Alat Peraga Blok Pecahan

Fungsi blok pecahan adalah untuk membantu guru mengajarkan konsep pecahan, mengurutkan pecahan tertentu dengan pecahan senilai. Alat peraga blok pecahan ini dapat dibuat dari bahan triplek, karton, kertas asturo/kertas berwarna, dan lain sebagainya. Bentuk alat dapat berupa persegi panjang atau lingkaran, seperti pada gambar berikut.

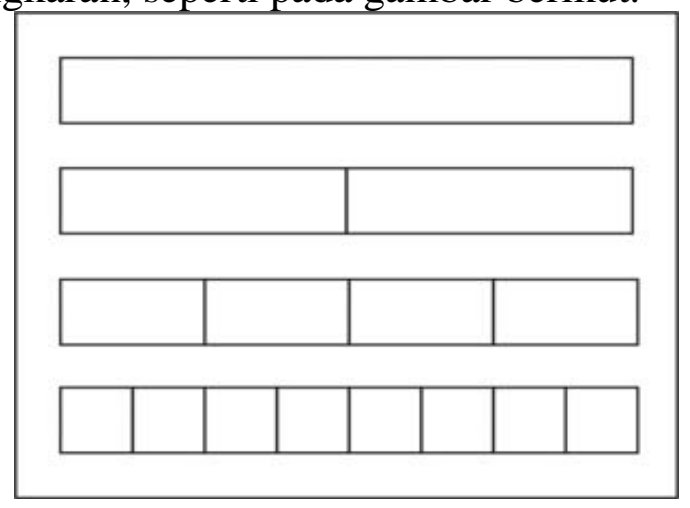

Model Blok Pecahan Persegi Panjang METODE PENELITIAN

Setting Penelitian

Penelitian ini adalah penelitian tindakan kelas (action research. Tujuan utama penelitian tindakan kelas ialah untuk meningkatkan praktik-praktik pembelajaran di kelas. Dalam kegiatan ini, semua yang tergabung dalam penelitian ini terlibat langsung secara penuh dalam proses perencanaan, tindakan, observasi, dan refleksi untuk memecahkan masalah pembelajaran secara kasuistis dan lokal (Mulyasa, 2012;37)

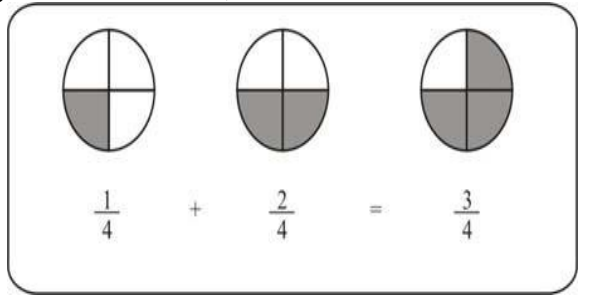

Penelitian ini dilaksanakan di SDN Tuban pada peserta didik Kelas II semester genap tahun pelajaran 2017/2018 
dengan jumlah peserta didik 34 orang, yang terdiri dari 13 perempuan dan 21 laki-laki..

\section{Subyek penelitian}

Subjek penelitian ini adalah siswa kelas II semester I SDN Tuban tahun pelajaran 2017/2018. Terdiri atas 34 siswa terdiri dari 21 siswa laki-laki dan 13 siswa perempuan. Mereka berasal dari berbagai latar belakang yang beragam yang terdiri atas keluarga, petani, pegawai, dan wiraswasta.

\section{Rencana Penelitian}

Penelitian ini dilaksanakan dalam dua siklus, masing-masing siklus dilaksanakan dalam 4 tahap, yaitu, (1) tahap perencanaan, (2) tahap pelaksanaan, (3) tahap pengolahan data, dan (4) penyusunan Laporan. Tahap-tahap tersebut dapat dirinci sebagai berikut

Penelitian dilaksanakan dalam dua siklus, siklus 1 pada tanggal 24 Januari 2018 dan silus 2 tanggal 21 Februari 2018, dengan menggunakan skema sebagai berikut :

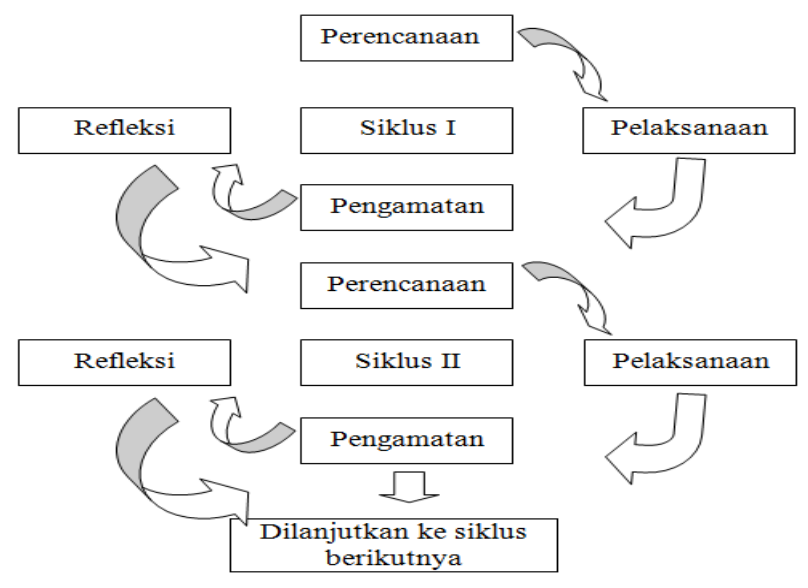

Gambar 3.2 Skema Model Penelitian

Tindakan Kelas(Arikunto, Suhardjono, Supardi, 2007)

Penelitian ini dilaksanakan sebanyak dua siklus/putaran.Observasi dibagi dalam dua putaran, yaitu putaran 1 , dan 2 , dimana masing putaran dikenai perlakuan yang sama (alur kegiatan yang sama) dan membahas satu sub pokok bahasan yang diakhiri dengan tes formatif di akhir putaran. Dibuat dalam dua putaran dimaksudkan untuk memperbaiki sistem pengajaran yang telah dilaksanakan.

Jenis Instrumen dan Cara Penggunaan

Menurut Sanusi yang dikutip oleh Supardi, instrumen penelitian adalah suatu alat yang digunakan oleh peneliti untuk mengukur fenomena alam atau gejala sosial.(Supardi 2011; 98) Dalam penelitian ini Peneliti menggunakan 4 metode pengumpulan data yang dianggap penting, yakni:

1. Pedoman Observasi

Observasi atau metode pengamatan mempunyai sifat dasar naturalistik yang berlangsung dalam konteks natural (asli) dari kejadian, pelakuannya berpartisipasi secara wajar dalam interaksi, dan observasi ini menelusuri aliran alamiah dari kehidupan sehari-hari.( Sedamayanti 2002;75)

2. Tes

Tes merupakan satu metode untuk mengukur tingkat kinerja individu. Tes digunakan peneliti untuk mengetahui hasil belajar peserta didik terhadap kegiatan pembelajaran dengan pengajaran reflektiv untuk memperoleh data dari tes tersebut, peneliti menyusun soal-soal berbentuk objektif dan tes lisan. Pemberian tes dilaksanakan setelah pelaksanaan pembelajaran dari masingmasing siklus. Di dalam penelitian, tes digunakan untuk mengukur hasil belajar siswa dalam pelajaran Matematika berbentuk tes unjuk kerja.

3. Dokumentasi

Dokumentasi adalah mencari hal-hal atau variabel yang berupa catatan, transkrip buku, surat kabar, majalah dan sebagainya. Keutamaan dari metode dokumentasi ini adalah sebagai bukti dalam suatu pengkajian yang bersifat alamiah yang sesuai dengan konteks yang mudah ditemukan dengan kajian isi.

Instrumen dalam penelitian ini digunakan secara runtun dan juga bersamaan dengan instrument lainnya. Observasi dilakukan saat kegiatan pembelajaran berlangsung, sementara angket digunakan setelah proses pembelajaran berlanjut yang dilanjutkan dengan wawancara untuk 
mendapatkan data hasil belajar peserta didik setelah menggunakan pengajaran reflektiv oleh Guru dalam pembelajaran Matematika Kelas II SDN Tuban Tahun Pelajaran 2017/2018.

Dalam penelitian ini, data yang dikumpulkan berasal dari catatan lapangan, dokumen pribadi, dan dokumen resmi lainnya. Oleh, karena itu penelitian ini termasuk kedalam penelitian kualitatif deskriptif. Penelitian ini juga menggunakan data kuantitatif dalam bentuk angka-angka diperoleh dari angket yang dilakukan untuk mengetahui sejauh mana motivasi peserta didik.

\section{Pelaksanaan Tindakan}

Pada siklus ini tahap yang dilakukan dalam penelitian ini adalah melalui empat tahap yaitu (1) perencanaan, (2) Pelaksanaan Perbaikan, (3) . Pengamatan (4) Refleksi demikian juga halnya pada siklus dua tahap yang dilaliu sama dengan siklus satu dengan melakukan perbaikan-perbaikan yang telah direkomendasi dari setiap langkah pelaksanaan

\section{Analisa Data dan Refleksi}

Untuk mengetahui keefektivan suatu metode dalam kegiatan pembelajaran perlu diadakan analisis data. Pada penelitian ini menggunakan teknik analisis dekriptif kualitatif, yaitu suatu metode penelitian yang bersifat menggambarkan kenyataan atau fakta sesuai dengan data yang diperoleh dengan tujuan untuk mengetahui hasil belajar yang dicapai siswa, juga untuk memperoleh respon siswa terhadap kegiatan pembelajaran serta aktivitas siswa selama proses pembelajaran.(Sudjana, 2007.98)

Untuk menganalisis tingkat keberhasilan atau prosentase keberhasilan siswa setelah proses belajar mengajar setiap siklusnya dilakukan dengan cara memberikan evaluasi berupa soal tes tertulis atau menilai unjuk kerja pada setiap akhir siklus .

Analisis ini dihitung dengan menggunakan statistik sederhana yaitu :

1. Untuk menilai ulangan atau tes formatif

Peneliti melakukan penjumlahan nilai

yang diperoleh siswa, yang selanjutnya dibagi dengan jumlah siswa yang ada di kelas tersebut sehingga diperoleh rata-rata tes

formatif dapat dirumuskan $: X=\frac{\Sigma x}{\Sigma \mathrm{N}}$

Dengan:

$$
\begin{aligned}
& \mathrm{X}=\text { Nilai rata-rata } \\
& \sum \mathrm{X}=\text { Jumlah semua nilai siswa } \\
& \sum \mathrm{N}=\text { Jumlah siswa }
\end{aligned}
$$

\section{Untuk ketuntasan belajar}

Ada dua kategori ketuntasan belajar yaitu secara perorangan dan secara klasikal. Berdasarkan petunjuk pelaksanaan belajar mengajar kurikulum 2017 yaitu seorang siswa telah tuntas belajar bila telah mencapai skor $65 \%$ atau nilai 65 , dan kelas disebut tuntas belajar apa bila di kelas tersebut terdapat $80 \%$ yang telah mencapai daya serap lebih dari atau sama dengan $65 \%$. Untuk menghitung presentase ketuntasan belajar digunakan rumus sebagai berikut :

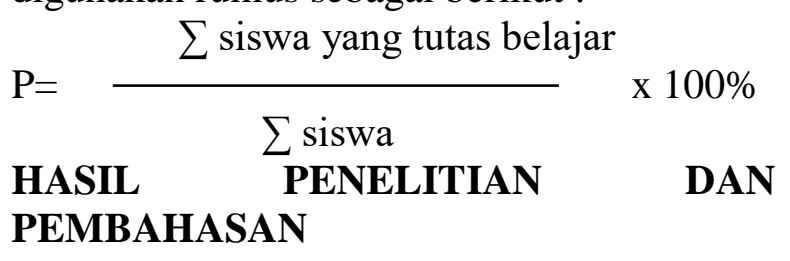

Deskripsi Hasil Penelitian.

Suklus 1.

Hasil tes mata pelajaran Matematika pada siklus I menunjukan bahwa nilai rata-ratanya yaitu 68,82 dari 19 siswa, siswa yang tuntas belajar sebanyak 12 orang atau persentase sebesar $63 \%$ dan jumlah siswa yang tidak tuntas sebanyak 7 orang atau sebesar $37 \%$. Ini terjadi karena berbagai faktor antara lain guru kurang mahir dalam mengajar dengan media. Karena target belum tercapai maka penelitian dilanjutkan kembali ke siklus selanjutnya.

Siklus 2

hasil tes pada siklus II yang diikuti oleh 19 orang,menunjukan bahwa nilai ratarata yang diperoleh adalah 81,17, jumlah siswa yang tuntas belajar sebanyak 19 orang atau persentase ketuntasan sebesar $95 \%$ ,jumlah siswa yang tidak tuntas sebanyak 1 orang atau sebesar $5 \%$ dari 19 siswa,dengan demikian maka ,ketuntasan belajar secara klasikal sudah tercapai $\geq 80 \%$ dari jumlah siswa ,dengan demikian maka penelitian ini dihentikan sampai siklus II. Hasilnya sudah menunjukkan hasil yang cukup signifikan 
Refleksi

Berdasarkan hasil refleksi yang dilakukan di siklus II menunjukan bahwa pembelajaran Matematika yang dilakukan di kelas II SDN Tuban dengan Menggunakan Media Kongkrit sudah berjalan lebih baik dan lancar dibandingkan dengan siklus I, karena pelaksanaan siklus II merupakan perbaikan dari siklus sebelumnya. Secara kuantitas terlihat dari hasil belajar yang meningkat secara signifikan dibandingkan siklus I.

\section{Pembahasan}

Penelitian yang dilaksanakan di SDN Tuban ini dilaksanakan dalam 2 siklus yaitu mulai dari bulan Januari sampai dengan bulan Maret 2018 .Dimana hasil yang diperoleh pada siklus I adalah sebagai berikut

Hasil tes mata pelajaran Matematika pada siklus I menunjukan bahwa nilai rata-ratanya yaitu 68,82 dari 19 siswa, siswa yang tuntas belajar sebanyak 12 orang atau persentase sebesar $63 \%$ dan jumlah siswa yang tidak tuntas sebanyak 7 orang atau sebesar $37 \%$. Ini terjadi karena berbagai faktor antara lain guru kurang mahir dalam mengajar dengan media. Karena target belum tercapai maka penelitian dilanjutkan kembali ke siklus selanjutnya.

Kemudian siklus II dilaksanakan pada hari senin tanggal 5 Maret 2018 yang diikuti oleh semua murid kelas II ,hasil tes mata pelajaran Mtematika pada siklus II ,menunjukan bahwa nilai rata-rata yang diperoleh adalah 81,17, jumlah siswa yang tuntas belajar sebanyak 18 orang atau persentase ketuntasan sebesar $95 \%$,jumlah siswa yang tidak tuntas sebanyak 1 orang atau sebesar $5 \%$ dari 19 siswa,dengan demikian maka ,ketuntasan belajar secara klasikal sudah tercapai $\geq 80$ yaitu ,dengan demikian maka penelitian ini dihentikan sampai siklus II. Hasilnya sudah menunjukkan hasil yang cukup signifikan

Dengan demikian terjadi peningkatan hasil yang cukup signifikan dimana pada siklus I nilai rata - rata yang diperoleh adalah 68,82 meningkat pada siklus II sebesar 81,17 disini terjadi peningkatan sebesar 12,35 poin.kemudian jumlah siswa yang tuntas pada siklus I sebanyak 12 orang atau persentase sebesar 63 dan pada siklus II jumlah siswa yang tuntas sebanyak 18 orang atau sebesar $95 \%$ terjadi peningkatan sebesar 32,35 poin jadi dengan demikian dapat ditarik kesimpulan bahwa pembelajaran Matematika di kelas II dengan menggunakan media kongkrit bisa dijadikan sebagai salah satu model pembelajaran.

\section{PENUTUP}

Hasil penelitian tindakan kelas (PTK) di kelas II SDN Tuban ini dapat disimpulkan bahwa" Penggunaan peraga benda kongrit materi pecahan pada mata pelajaran matematika di kelas II SDN Tuban dapat meningkatkan hasil belajar siswa dilakukan sebanyak 2 siklusnilai rata - rata yang diperoleh adalah 68,82 meningkat pada siklus II sebesar 81,17 disini terjadi peningkatan sebesar 12,35 poin.kemudian jumlah siswa yang tuntas pada siklus I sebanyak 12 orang atau persentase sebesar 63 dan pada siklus II jumlah siswa yang tuntas sebanyak 18 orang atau sebesar $95 \%$ terjadi peningkatan sebesar 32,35 poin jadi dengan demikian dapat ditarik kesimpulan bahwa pembelajaran Matematika di kelas II, Dengan demikian maka dapat disimpulkan bahwa penggunaan peraga benda kongrit dapat meningkatkan hasil belajar siswa pada Pelajaran Matematika khususnya Penjumlahan Pecahan.

\section{DAFTAR PUSTAKA}

Antonius Cahya Prihandoko. (2006). Memahami konsep matematika secara benar dan menyajikannya dengan menarik. Jakarta: Depdiknas Dirjen Dikti Direktorat Ketenagaan.

Arif Rohman. (2009). Memahami Pendidikan \& Ilmu Pendidikan. Yogyakarta: Laksbang Mediatama.

Ariyadi Wijaya. (2012). Pembelajaran Matematika Realisik. Yogyakarta: Graha Ilmu.

Daitin Tarigan. (2006). Pembelajaran Matematika Realistik. Jakarta: Depdiknas

Dwi Siswoyo, dkk. (2007). Ilmu Pendidikan. Yogyakarta: UNY Press.

John W. Santrock. (2010). Psikologi Pendidikan. Jakarta: Kencana.

KTSP. (2007).Kurikulum Tingkat Satuan Pendidikan. Jakarta: BP Cipta Jaya 
Gatot MuhSetyo, dkk 20014. Pembelajaran Matematika di SD , PDGK.4406, Universitas terbuka . Banten Indonesia

Hasibuan Proses Belajar Mengajar II, Malang:I ..2008, Undang-Undang RI No 20 Tahun 2003 tentang Sisdiknas ,Sinar Garfika

Mohammad Asrori, 2009. Psikologi pembelajaran, Wacana Prima

Ngalim Purwanto. (2006). Prinsip-prinsip dan Teknik Evaluasi Pengajaran. Bandung: Rosdakarya.

Nurul Zuhriah 2009 . Metodologo Penelitian Sosial dan Pendidikan, TeoriAplikasi, Sinar Garfika 